\title{
BIOLOGIA VERSUS KULTURA. PRZEGLĄD BIOEWOLUCYJNYCH I KULTUROWYCH TEORII WOJNY W PRZEDPAŃSTWOWYCH SPOLECZNOŚCIACH PRADZIEJOWYCH
}

\author{
BIOLOGY VERSUS CULTURE. AN OVERVIEW \\ OF BIOEVOLUTIONARY AND CULTURAL THEORIES \\ OF WARFARE IN PREHISTORIC PRESTATE SOCIETIES
}

\author{
Rafat Skrzyniecki \\ Instytut Archeologii, Wydział Historyczny, Uniwersytet im. Adama Mickiewicza \\ ul. Umultowska 89D, 61-614 Poznań, Poland \\ rskrzyniecki@gmail.com \\ Jan Romaniszyn \\ Instytut Archeologii, Wydział Historyczny, Uniwersytet im. Adama Mickiewicza \\ ul. Umultowska 89D, 61-614 Poznań, Poland \\ janrom89@wp.pl
}

\begin{abstract}
The paper's main aim is to outline the problem of polarisation of contemporary discussion concerning the concept of origins of warfare. Basically, two leading trends can be distinguished: the first one accentuates the biological basis of human violence and places its origins deep into our evolutionary past. The second one recognises conflict as a relatively late and typically cultural phenomenon in human prehistory, which cannot be interpreted in terms of natural selection and evolution. The existence of a sharp ideological border between 'hawks' and 'doves' enables a comparison of both perspectives and facilitates the analysis of internal dynamics of their development.
\end{abstract}

KEY WORDS: warfare, origins, Killer Ape Theory, cultural materialism, sociobiology

\section{WPROWADZENIE}

Dyskusja poświęcona problematyce „warfare” w społecznościach przedpaństwowych - zarówno tych pradziejowych, jak i będących przedmiotem badań etnografów - nosi wyraźne znamiona polaryzacji (np. LeBlanc, Register 2003; Pinker 
2011; Gat 2006; Guilaine, Zammit 2005; Ferguson 1990, 2006, 2008, 2013; Haas 1998; Fry 2013). W ramach studiów nad tym zagadnieniem wydziela się dwie wiodące tendencje badawcze o skrajnie odmiennej wymowie. Ich przedstawicieli przyjęło się nazywać ,jastrzębiami” i ,gołębicami” (Keeley 1996; Otterbein 2004). Oba terminy nawiązują do podziałów obowiązujących na współczesnej międzynarodowej scenie politycznej (Keeley 1996; Otterbein 2004). Pierwszy z nich określa zwolenników retoryki prowojennej, drugi natomiast odnosi się do środowisk o bardziej umiarkowanych, często wręcz pacyfistycznych poglądach. Korzenie sporu między „jastrzębiami” i ,gołębicami’ sięgają najprawdopodobniej okresu rozwoju nowożytnej myśli filozoficznej (por. Dawson 1996).

Współczesne studia nad „warfare” oscylują wokół trzech kluczowych pytań badawczych: czy wojna odegrała istotną rolę w ewolucji gatunku ludzkiego; czy przemoc to praktyka uwarunkowana biologicznie, czy kulturowo oraz jakie są przyczyny wojen w społecznościach przedpaństwowych (Przybyła 2014). Przedstawiciele obozu ,jastrzębi" uważają działania wojenne za jeden z podstawowych czynników warunkujących ewolucję gatunku homo - zarówno w sensie biologicznym, jak i społecznym (Gat 2006; Wrangham i Peterson 1999; Chagnon 2013; Tooby, Cosmides 1988). Ich zdaniem praktyka ta ma podłoże biologiczne i wynika bezpośrednio z natury ludzkiej. Do konfliktów dochodzi więc w wyniku splotu okoliczności natury biologiczno-ewolucyjnej, tj. wskutek naturalnej inklinacji do przemocy oraz dążenia do zapewnienia sobie sukcesu reprodukcyjnego kosztem innych jednostek i społeczności. Wykładnia teorii „warfare” według „,gołębic” prezentuje się zgoła odmiennie: w zależności od przyjętego paradygmatu wojna może być zdarzeniem o charakterze losowym, w zasadzie pozbawionym wpływu na funkcjonowanie społeczności w nią uwikłanych (Mead 1940); produktem ubocznym procesu ewolucji struktur społecznych; wynikiem konkurencji o dostęp do kluczowych surowców (np. Ferguson 2008) lub mechanizmem demograficznym, odpowiedzialnym za utrzymanie liczebności populacji ludzkiej na poziomie umożliwiającym zrównoważoną eksploatację zasobów środowiska (Harris 2006). Zasygnalizowany w tytule artykułu podział teorii wojny na bioewolucyjne i kulturowe odzwierciedla różnice w pojmowaniu istoty „warfare” przez przedstawicieli obu obozów.

\section{NOWOŻYTNE KONCEPCJE WOJNY ORAZ ICH MIEJSCE W REFLEKSJI NAD EWOLUCJĄ GATUNKU LUDZKIEGO}

Geneza sporu doktrynalnego między ,jastrzębiami” i „gołębicami” może sięgać XVII/XVIII w. Pogląd ten znajduje odzwierciedlenie w pracach dwóch myślicieli, których twórczość dzieli okres przeszło stu lat. Mowa tu o Tomaszu Hobbesie i Janie Jakubie Rousseau. Pierwszego z nich można w pewnym sensie uznać za prekursora opcji „prowojennej”. W swoim dziele zatytułowanym Lewiatan, czyli mate- 
ria, forma i wtadza państwa kościelnego i świeckiego $(2005)^{1}$ ogłosił tezę, że wojna $\mathrm{w}$ zasadzie nie tyle leży w, co JEST naturą człowieka. Archetypiczny state of nature to $\mathrm{w}$ istocie state of warre, a zatem stan wyniszczającej, permanentnej wojny. Postępowaniem wszystkich ludzi kieruje deterministyczna siła - animus dominandi, na którą składają się skrajny egoizm oraz pragnienie władzy. Ludzie biernie poddają się działaniu tej siły, co nieuchronnie prowadzi do upowszechnienia się jedynej racjonalnej strategii interakcji, tj. konfliktu. Według T. Hobbesa pierwotne relacje społeczne były kształtowane przez powszechną żądzę posiadania. Nieustająca obawa przed utratą mienia i życia zmuszała do aktywnej obrony polegającej na organizowaniu ataków wyprzedzających $\mathrm{w}$ celu zniechęcenia potencjalnego agresora do podjęcia wrogich działan. Ów filozof jako pierwszy sformułował jedno z podstawowych i wciąż jeszcze aktualnych pytań badawczych: czy człowiek wykazuje naturalną skłonność do przemocy? T. Hobbes udzielił odpowiedzi twierdzącej, a jego koncepcja stała się punktem wyjścia dla późniejszych pokoleń badaczy forsujących koncepcję długiej genezy wojny.

Jednym z najsłynniejszych XIX-wiecznych kontynuatorów myśli hobbesowskiej był brytyjski filozof i socjolog Herbert Spencer. Uznaje się go za twórcę tzw. darwinizmu społecznego - nurtu badawczego inspirowanego lamarkizmem, łączącego wątki biologicznej i społecznej ewolucji gatunku homo. Podobnie jak T. Hobbes, wyszedł on z założenia, że genezę wojny należy wiązać z najwcześniejszymi etapami rozwoju społeczności ludzkich. Praktyce tej przypisywał dwojakie znaczenie: w warunkach konfliktu przetrwanie było udziałem jedynie najlepiej przystosowanych jednostek (kanoniczne survival of the fittest), u których doszło do ponadprzeciętnego rozwoju określonych cech, umożliwiających efektywną egzystencję w skrajnie nieprzyjaznym otoczeniu. W wyniku selekcji naturalnej podlegały one dziedziczeniu, co w perspektywie ewolucyjnej dodatkowo zwiększało zdolność reprodukcyjną kolejnych pokoleń. $Z$ drugiej strony sukces na wojnie był uzależniony od współpracy między jednostkami - zwycięstwa odnosiły społeczności najlepiej zorganizowane, skupiające jednostki przedkładające dobro ogółu nad interes własny (1851). H. Spencer uważał kooperację za jeden z fundamentów rozwoju cywilizacji, dlatego też przypisywał wojnie szczególne znaczenie w procesie komplikacji struktur społecznych. W przeciwieństwie do T. Hobbesa uważał więc, że „warfare” to działanie o charakterze utylitarnym. Wyznaczył jednak istotną cezurę $\mathrm{w}$ jej rozwoju - wraz z nastaniem cywilizacji wojna przestawała odgrywać rolę motoru ewolucji (1851).

Koncepcja H. Spencera stanowi twórcze rozwinięcie wykładni hobbesowskiej (Dawson 1999, 2001). Dla obu autorów przemoc była jednym z czynników towarzyszących kształtowaniu się pierwszych społeczności ludzkich. Różni ich natomiast ocena funkcji tego zjawiska. Według T. Hobbesa wojna ma wymiar pejoratywny -

\footnotetext{
${ }^{1}$ Książkę po raz pierwszy opublikowano w 1651 w Londynie.
} 
jest deterministyczną siłą uwikłaną w ludzką naturę, przez którą człowiek nie może wejść na ścieżkę postępu. W takich warunkach walka toczy się w myśl zasady „wszyscy przeciw wszystkim”. Sposobem na wyjście z tego impasu jest zawarcie przymierza między społecznościami, na mocy którego wyłoniona zostanie jednostka lub instytucja obdarzona władzą związaną z monopolem na użycie przemocy, lecz tylko w określonych okolicznościach, tzn. w celu obrony innych oraz karania sprawców napaści (por. Keeley 1996). Wojna towarzyszy zatem człowiekowi od początku jego istnienia, ale pierwotnie jako niekontrolowany żywioł, podsycany dodatkowo jego naturalnymi skłonnościami do przemocy. Dopiero kodyfikacja oraz skuteczna egzekucja praw pozwala uczynić z niej narzędzie do realizacji celów politycznych oraz kładzie solidny fundament pod dalszy rozwój społeczno-kulturowy. Natomiast dla H. Spencera wojna nie jest przeszkodą, lecz gwarantem progresu. Ponadto ów autor nie doszukuje się przyczyn konfliktów wyłącznie w naturze ludzkiej, podobnie jak Tomasz Malthus rolę czynnika inicjującego wojnę przypisuje bowiem presji demograficznej (Dawson 1996).

Spencerowska koncepcja wojny straciła na znaczeniu w początkach XX w., gdy ostatecznie udowodniono, że opiera się na fałszywych przesłankach naukowych (Dawson 1996, s. 11). Podstawą teoretyczną dla darwinizmu społecznego był bowiem lamarkizm - pierwsza opublikowana teoria ewolucji postulująca m.in. dziedziczenie cech nabytych w trakcie życia osobniczego. Akceptacja tez lamarkizmu pozwalała darwinistom społecznym na łączenie ewolucji biologicznej ze społeczną. Ich zdaniem jednym z czynników decydujących o lepszym dostosowaniu społeczności była powszechność działań o charakterze altruistycznym. Jednak koncepcję tę obalono, w związku z czym problem ewolucji społeczności ludzkich został pozbawiony bazy teoretycznej. Renesans studiów nad owym zagadnieniem nastąpił dopiero w latach 70. XX w., aczkolwiek pewne próby rewitalizacji mitu ,brutalnego dzikiego" pojawiły się już wcześniej.

\section{BIOEWOLUCYJNE TEORIE WOJNY}

\section{Teoria zabójczej malpy i Hunting Hypothesis}

W wyniku obalenia tez lamarkizmu darwinizm społeczny został zepchnięty na margines debaty naukowej w pierwszej połowie XX w. Doprowadziło to do upowszechnienia się determinizmu kulturowego - nowego kierunku badań w naukach humanistycznych. Odznaczał się on skrajną niechęcią do zdawałoby się przebrzmiałych teorii ewolucyjnych. W ich miejsce proponował zupełnie nowy model badawczy postulujący nadrzędną rolę kultury w procesie rozwoju grup ludzkich. Niemniej idea wrodzonej skłonności do agresji nie została całkowicie zapomniana. Pamięć o niej przetrwała m.in. dzięki Zygmuntowi Freudowi, który w swojej korespondencji 
z Albertem Einsteinem dał wyraz dalekim od pacyfistycznych poglądom na problem genezy wojny i jej związku z naturą ludzką. Uważał, że wojna jest zakorzeniona w ,instynkcie śmierci”, rozumianym jako chorobliwa żądza agresji i zniszczenia, wynikająca z biologicznych uwarunkowań człowieka (za Dawson 1996, 13-14). Koncepcję tę uznawano w pewnych kręgach za prawdopodobną, aczkolwiek w latach 30. XX w. nie dysponowano jeszcze aparatem badawczym pozwalającym na otrzymanie bezpośrednich dowodów na słuszność freudowskich tez. Pewnym preludium do ponownego rozkwitu myśli neohobbezjańskiej były pojedyncze próby wznowienia studiów nad aktami przemocy wśród wczesnych hominidów. Matt Cartmill, który badał problem rozwoju teorii zabójczej małpy w naukach przyrodniczych i społecznych, wskazuje na trzech autorów próbujących wskrzesić ten mit: Charlesa Morrisa, Harrego Campbella oraz Carvetha Reada (za Otterbein 2004). Zaznacza jednak, że ich propozycje nie wywarły praktycznie żadnego wpływu na ówczesną debatę naukową i stanowią obecnie jedynie ciekawostkę historyczną. W zasadzie można zaryzykować stwierdzenie, że o powrocie darwinizmu na grunt nauk społecznych zadecydował przypadek. Kiedy Raymond Dart ogłosił w 1924 r. odkrycie nowej formy hominida - australopiteka, środowisko naukowe przyjęło tę informację z rezerwą. Wciąż bowiem fascynowano się znaleziskiem z Piltdown w hrabstwie Sussex, gdzie w trakcie eksploracji żwirowiska natrafiono na skamieniały szczątki istoty, którą jednogłośnie uznano za brakujące ogniwo ewolucji między człowiekiem i małpą (por. Sussman, Marschack 2010). Odnaleziona czaszka odznaczała się bardzo dużą pojemnością puszki mózgowej oraz archaiczną budową żuchwy. Przez ponad 40 lat odkrycie uważano za kanoniczne. Jednak w 1953 r. ostatecznie wykazano, że niezwykłość Człowieka z Piltdown jest wynikiem oszustwa. Czaszka składała się z dwóch odrębnych, sztucznie połączonych części - część górna należała do rdzennego mieszkańca Ziemi Ognistej, natomiast żuchwa pochodziła od orangutana. W związku z zaistniałymi wydarzeniami tytuł najwcześniejszego znanego hominida przyznano australopitekowi (Otterbein 2004).

Ponowna analiza stale przybywającego materiału kostnego skłoniła Raymonda Darta do zmiany dotychczasowych poglądów na funkcjonowanie owego gatunku. Pierwotnie uznał on rzeczonego hominida za drobnego padlinożercę. Jednakże rozpoznane przez niego ślady uszkodzeń na kościach doprowadziły go do skrajnie odmiennych wniosków. Ów badacz ogłosił, że stanowią one podstawę do uznania australopiteka za aktywnego łowcę, używającego narzędzi nie tylko do zabijania i oprawiania zwierzyny, ale również innych przedstawicieli własnego gatunku (Dart 1953). Zdaniem wspomnianego już M. Cartmilla koncepcja brutalnej natury najstarszego przodka człowieka była silnie inspirowana poglądami filozofów greckich i chrześcijańskich. Świadczy o tym m.in. sentencja otwierająca pracę Darta (por. Sussman, Marschack 2010), będąca wyjątkiem z dzieła XVII-wiecznego pisarza tworzącego w duchu kalwinizmu R. Baxtera: of all the beasts the man-beast is the worst/to others and himself the cruelest foe ( $\mathrm{w}$ wolnym thumaczeniu: spośród 
wszystkich bestii człowiek jest tą najgorszą/dla innych i dla siebie będąc najokrutniejszym wrogiem - tłum. aut.). Badania R. Darta wyznaczyły nowy kierunek refleksji nad genezą przemocy zorganizowanej w kontekście gatunku homo. Według hunting hypothesis, ponieważ takim mianem przyjęło się określać teorię wspomnianego badacza, wojna stanowiła rozwinięcie najstarszych praktyk łowieckich. Ze względu na swoje pokrewieństwo z małpami roślinożernymi, pierwsze hominidy nie posiadały właściwego drapieżnikom instynktu wzbraniającego przed zranieniem lub zabiciem przedstawiciela własnego gatunku (Dawson 1996, s. 16). Ponadto umiejętność posługiwania się narzędziami pozwalała im na dokonanie zabójstw bez konieczności angażowania się w bezpośrednią walkę.

\section{Socjobiologia}

Prawdziwy przewrót naukowy w dziedzinie aplikacji darwinizmu we współczesnych badaniach nad wojną dokonał się jednak kilkanaście lat później za sprawą angielskiego biologa Williama Hamiltona. Jego praca poświęcona zachowaniu owadów eusocjalnych dostarczyła dowodów na potwierdzenie hipotezy, że selekcja naturalna zachodzi również w przypadku grup organizmów, nie zaś - jak uważał Karol Darwin - wyłącznie jednostek (Dawson 1999, s. 85). Odkrycie to zrewolucjonizowało również sposób myślenia o zachowaniu przedstawicieli przedpaństwowych społeczności ludzkich. E.O. Wilson, jeden z czołowych reprezentantów nowopowstałego nurtu socjobiologicznego, zaproponował autorską interpretację praktyki „warfare”. Jego zdaniem każda społeczność ludzka wykazuje naturalną tendencję do wrogości wobec osobników obcych. Dzięki temu więzi między członkami grupy ulegają zacieśnieniu, a wszelkie przejawy agresji kierowane są na zewnątrz. Taka ksenofobiczna, etnocentryczna postawa ma podłoże genetyczne, ponieważ jest rezultatem doboru krewniaczego (1978). Koncepcja E.O. Wilsona unowocześniła bazę teoretyczną dartowskiej hunting hypothesis. Jej dotychczasowa wykładnia operowała bowiem bliżej nieokreśloną kategorią zabójczego instynktu, będącego podstawowym czynnikiem warunkującym rozwój przemocy w obrębie gatunku. Socjobiologia proponuje odmienne rozumienie istoty owego zjawiska. Wojna to strategia adaptacyjna nastawiona na maksymalizację skuteczności procesów reprodukcyjnych, w myśl altruistycznej zasady doboru krewniaczego. Młodzi mężczyźni podejmują ryzyko związane $\mathrm{z}$ uczestnictwem $\mathrm{w}$ działaniach wojennych $\mathrm{w}$ celu zabezpieczenia puli genowej obejmującej również ich najbliższych krewnych. W związku z tym nawet jeśli jednostka poniesie śmierć, jej geny zachowają dotychczasowe lub zyskają nowe możliwości sukcesji, co w ogólnym rozrachunku przyczyni się do dalszego rozwoju grupy pokrewieństwa. Ponadto ze względu na obecność wspomnianych wcześniej uniwersaliów behawioralnych adaptacyjna rola wojny wykracza poza ramy grupy najbliższych krewnych i odnosi się do ogółu społeczności 
ludzkich. Obok funkcji konsolidujących spoistość grupy, wojna stymuluje również proces ewolucji społecznej w jej wymiarze zewnętrznym. Według Richarda Alexandra ewolucyjna rola „warfare” ulegała zmianie wraz z rozwojem zjawiska. Początkowo małe grupy hominidów organizowały się dla skuteczniejszej obrony przed drapieżnikami. Kolejnym krokiem było rozpoczęcie działalności łowieckiej. W wyniku jej rozwoju pojawiła się konieczność zabezpieczenia się przed atakiem ze strony innych grup łowców. Na końcu tego ciągu R. Alexander umieszcza wspomnianą potrzebę bezpieczeństwa. Miała ona regulować przebieg działań zbrojnych społeczności przepdaństwowych w myśl zasady „równowagi władzy”, tj. dążenia do zawierania koalicji $\mathrm{w}$ celu redukcji zagrożenia związanego $\mathrm{z}$ nadmiernym wzrostem potencjału militarnego jednej z grup (1979).

\section{Kognitywne mechanizmy adaptacji do „warfare”. Psychologia ewolucyjna i Risk Contract of War}

„Warfare” to jedna z form przemocy, w której udział biorą co najmniej dwie autonomiczne grupy osobników. Jej celem jest zaspokojenie potrzeb członków danej populacji kosztem innych uczestników konfliktu. Znaczna niekiedy liczba uczestników tych działań rodzi konieczność przeanalizowania mechanizmów interakcji między jednostkami tworzącymi grupę wojenną. Jednakże z pewnych względów wojna praktycznie nie występuje w świecie zwierząt. Jest to o tyle zaskakujące, że w większości przypadków podjęcie współpracy między słabszymi jednostkami mogłoby znacząco zwiększyć ich szanse na przełamanie supremacji dominującego samca, a tym samym na skuteczną reprodukcję (Tooby, Cosmides 1988, s. 2). Elitarność omawianej praktyki wynika z licznych warunków, jakie gatunek musi spełniać, by zakończyła się ona powodzeniem. Podstawowym kryterium jest potencjał kognitywny (Cosmides 1985). W tym konkretnym przypadku odnosi się on do umiejętności wykrycia, identyfikacji i wykluczenia osobników, których obecność obniża szanse powodzenia danej koalicji. O ich skutecznym wykorzystaniu decydują tzw. algorytmy darwinowskie, czyli wykształcone w toku ewolucji mechanizmy przetwarzania informacji. Jak dotąd udało się wskazać jedynie dwa gatunki, które mają odpowiednie predyspozycje umożliwiające podjęcie działań w typie „warfare” - są to ludzie i szympansy. Według Johna Tooby'ego i Leny Cosmides konflikty między plejstoceńskimi społecznościami łowiecko-zbierackimi były częstym zjawiskiem (1988, s. 4). Doprowadziło to do selekcji określonych mechanizmów psychologicznych, regulujących postępowanie osobników zarówno w stosunku do sprzymierzonych jednostek należących do tej samej koalicji, jak i przedstawicieli wrogich populacji. Wzorce te podlegały dziedziczeniu i występują również $\mathrm{u}$ współczesnych ludzi, aczkolwiek obecnie funkcjonują w zupełnie odmiennych kontekstach, często niezgodnie z pierwotnym przeznaczeniem. 
O powodzeniu działania koalicyjnego w warunkach konfliktu decyduje kilka czynników. Są to: stopień ryzyka utraty zdrowia lub życia, ocena wkładu poszczególnych uczestników koalicji w osiągnięcie zamierzonego celu, prawdopodobieństwo powodzenia, łączna wartość potencjalnych korzyści oraz warunki udziału w tychże. Składają się one na tzw. Risk Contract of War, a więc akceptację ryzyka związanego z udziałem w „,warfare”. Umiejętność oceny tych czynników jest wynikiem działania wzmiankowanych algorytmów darwinowskich. Należy zaznaczyć, że stopień gotowości do wejścia „na wojenną ścieżkę” jest wprost proporcjonalny do wysokości szans na zwycięstwo (1988, s. 5). J. Tooby i L. Cosmides uznają wojnę za praktykę zwiększającą prawdopodobieństwo sukcesu reprodukcyjnego, jeżeli: ryzyko śmierci lub obrażeń jest takie samo dla wszystkich uczestników, działanie ma duże szanse powodzenia, zwycięzcy w równym stopniu partycypują w korzyściach wynikających $\mathrm{z}$ wygranej oraz zero-jedynkowej struktury zysku. Ostatni z warunków odnosi się do społeczności poligynicznych, w których śmierć jednych uczestników koalicji wojennej nie ogranicza szans pozostałych walczących na udaną reprodukcję. Jako że miarą skuteczności danej praktyki jest uśredniony pomiar jej efektów, mierzony w czasie trwania ewolucji, to wojna, mimo związanego $\mathrm{z}$ nią realnego ryzyka utraty zdrowia lub życia, stanowi działanie prowadzące do zwiększenia ogólnego współczynnika reprodukcji (1988).

\section{Rewitalizacja teorii zabójczej małpy. Koncepcja „demonicznych samców” Richarda Wranghama}

Ostatnia $\mathrm{z}$ omawianych bioewolucyjnych teorii wojny stanowi w zasadzie podsumowanie dotychczas prezentowanych koncepcji. Nawiązuje ona do idei filogenetyczności, w myśl której ludzie wykazują znaczny stopień pokrewieństwa z małpami człekokształtnymi, w szczególności zaś z gatunkiem Pan troglodytes. Według najnowszych badań paleogenetycznych do rozdzielenia linii rozwojowych człowieka i szympansa doszło w okresie między 6 a 4,5 mln lat temu. Bazując na założeniu o bliskości genetycznej, R. Wrangham wysuwa przypuszczenie, że występowanie określonych form zachowania u obu gatunków może dowodzić, że najprawdopodobniej pojawiły się już u ich wspólnego przodka, żyjącego między 8 a $6 \mathrm{mln}$ temu (1999, 2010). Uwaga autora odnosi się w szczególności do praktyki „warfare”. Wieloletnie obserwacje żyjących na wolności szympansów dostarczyły wiarygodnych dowodów potwierdzających istnienie konfliktów między grupami tych małp. R. Wrangham uważa również, że zasady strukturyzujące przebieg wojny u Pan troglodytes są bardzo zbliżone do taktyki walki przedstawicieli społeczności przedpaństwowych. Autor wskazuje, że w obu przypadkach akty zorganizowanej przemocy mają wymiar koalicyjny i skierowane są na zewnątrz, co pozwala zaklasyfikować je jako przejawy „warfare”. Co więcej, do ataku na przedstawicieli obcej grupy do- 
chodzi wyłącznie w określonych warunkach. Decydującą rolę odgrywa w tym przypadku kryterium liczebności. Zarówno szympansy, jak i wojownicy społeczności przedpaństwowych przypuszczają atak jedynie w sytuacji, gdy dysponują przewagą liczebną pozwalającą na minimalizację ryzyka utraty zdrowia lub życia. W przypadku napotkania zdecydowanego oporu agresorzy z reguły odstępują od dalszych działań. Co więcej, oba gatunki regularnie wykorzystują element zaskoczenia w celu zwiększenia skuteczności napadu. Podstawowym celem zabójstw koalicyjnych u szympansów jest uzyskanie dostępu do ograniczonych „zasobów” partnerek seksualnych w celu zwiększenia szans na sukces reprodukcyjny. Stopniowa eliminacja samców z obcej grupy prowadzi zazwyczaj do eksterminacji całej męskiej części wrogiej populacji, a w następstwie redukcji konkurencji oraz, docelowo, przejęcia obcych samic. Podobnie jak pozostałe teorie bioewolucyjne koncepcja R. Wranghama, nazywana przez niego imbalance-of-power hypothesis, dostarcza argumentów na rzecz odległej genezy „warfare” (2010). Zakłada ona, że wojna rozwinęła się jeszcze na etapie ewolucji gatunku ludzkiego i spełniała funkcje adaptacyjne, w związku z czym należy ją uznać za zjawisko niejako wpisane w naturę ludzką. Wobec braku materialnych świadectw „warfare” z okresów wcześniejszych niż epipaleolit/mezolit (por. Ferguson 2013) jest to w zasadzie jedyna linia argumentacji „jastrzębi”. Na bazie wyników badań biologów i antropologów zwolennicy opcji prowojennej ukuli popularną frazę „,brak dowodów nie jest dowodem na brak zjawiska" (absence of evidence is not evidence of absence). Ma ono thumaczyć nierównomiernej reprezentacji archeologicznych świadectw „warfare” na przestrzeni dziejów gatunku ludzkiego.

\section{RUSSOJAŃSKA KONCEPCJA WOJNY I JEJ ROLA W KSZTALTOWANIU SIE „KULTUROWYCH” TEORII „WARFARE”}

W 1762 r., a zatem nieco ponad sto lat po Lewiatanie T. Hobbesa, ukazała się publikacja francuskiego filozofa Jana Jakuba Rousseau pt. Umowa Spoteczna, w której wyłożył on podstawy swojej koncepcji dotyczącej genezy konfliktów w przedpaństwowych społecznościach ludzkich. Propozycja ta odwoływała się do antycznej idei Złotej Ery społeczeństwa, czytelnej m.in. w pismach takich autorów jak Owidiusz czy Seneka (por. Dawson 1996). Zgodnie z jej wykładnią ludzkość rozwijała się na początku w sprzyjających warunkach społeczno-środowiskowych. Niewielka gęstość zaludnienia, znaczna dyspersja osadnictwa oraz obfitość surowców kluczowych dla przetrwania ograniczały ryzyko wystąpienia konfliktu praktycznie do minimum. Dodatkowym gwarantem harmonijnej, pokojowej egzystencji była powszechna afirmacja praw natury odzwierciedlających ład społeczny panujący przed pojawieniem się instytucji władzy oraz kodyfikacją prawa. Według J.J. Rousseau podstawową przyczyną konfliktów było wejście na ścieżkę postępu, prowadzą- 
cą do przekroczenia progu cywilizacyjnego. Pojawienie się ograniczeń o charakterze kulturowym, takich jak władza scentralizowana, własność prywatna oraz monogamicznej instytucji małżeństwa doprowadziło do zaburzenia pierwotnej harmonii i w efekcie doprowadziło do rozwoju alternatywnej, brutalnej strategii interakcji konfliktu zbrojnego. Idea ta stanowi w zasadzie odwrócenie retoryki T. Hobbesa, dla którego kultura była czynnikiem redukującym naturalną skłonność człowieka do przemocy. Obie koncepcje wywarły ogromny wpływ na rozwój późniejszej debaty nad genezą i istotą zjawiska przemocy zorganizowanej, zapoczątkowując niechlubny spór doktrynalny między ,jastrzębiami” i ,gołębicami”.

\section{Schyłek darwinizmu społecznego jako przyczynek do rozwoju nurtu neorussojańskiego w naukach społecznych}

Falsyfikacja tez lamarkizmu przełożyła się na spadek znaczenia ewolucyjnych koncepcji rozwoju społeczności ludzkich. Okazało się bowiem, że powszechna dotąd praktyka łączenia biologicznej i społecznej ewolucji gatunku homo sapiens oparta była na błędnych przesłankach teoretycznych (por. Dawson 1999). Badania G. Mendla wykazały jednoznacznie, że cechy nabyte w trakcie życia osobniczego nie mogą być przedmiotem sukcesji genetycznej (Dawson 1999). Niechęć do obalonej teorii darwinizmu społecznego była szczególnie silna wśród przedstawicieli dynamicznie rozwijającej się w początkach XX w. amerykańskiej antropologii kulturowej. Jej czołowy przedstawiciel Franz Boas, wespół z grupą swoich prominentnych uczniów, wysunął alternatywną koncepcję rozwoju grup ludzkich, w których główne miejsce zajmowała kultura. Nawiązywała ona do myśli znakomitego francuskiego socjologa Emila Durkheima, który postrzegał kulturę jako twór superorganiczny, poddający się analizie jedynie w kontekście innych treści kulturowych (1895). W owym ujęciu interesujące nas zjawisko stanowiło zatem twór niezależny wobec wszelkich uwarunkowań biologicznych, których znaczenie redukowano do minimum. Ze względu na postulat o dominującej roli kultury przyjęło się ów nurt określać mianem determinizmu kulturowego. Jego przedstawiciele uważali, że obowiązujące $\mathrm{w}$ danej społeczności formy zachowania są wynikiem działania nieuświadomionych wzorów kultury. Była to relacja jednostronna, ponieważ jednostka nie mogła w żaden sposób wpływać na charakter tych wzorów. Samą wojnę postrzegano jako wydarzenie losowe - chwilowe zaburzenie procesu adaptacji, pozbawione wpływu na funkcjonowanie danej społeczności. Pogląd ten został wyraźnie wyartykułowany w pracy Margaret Mead War is only an Invention - not a biological Necessity” (1940). Myślą przewodnią publikacji było przypisanie wojnie rangi „historycznego przypadku, przeżywającego się wyłącznie dzięki sile przyzwyczajenia". M. Mead zgadzała się z twierdzeniem, że „wojna pierwotna” służyła wielu doraźnym celom. Nie spełniała jednak żadnej istotnej funkcji: [It might] accumulate pres- 
tige or avenge their honor or acquire loot or wives or slaves or sago lands or cattle or appease the blood lust of their gods or the restless souls of the newly dead (Mead 1940).

Była to jednak koncepcja o skrajnej wymowie, popularna przede wszystkim w kręgach antropologów amerykańskich. Natomiast rozwój europejskiej refleksji nad istotą „warfare” w społecznościach przedpaństwowych podążył w odmiennym kierunku. W swojej pracy Anthropological Analysis of War (1940) Bronisław Malinowski zasugerował, że wojny społeczeństw pierwotnych oraz współczesne, konwencjonalne konflikty to zjawiska na tyle różne, że powinno się je rozpatrywać w im właściwych, skrajnie odmiennych kontekstach. Ponadto B. Malinowski jako pierwszy powiązał występowanie różnych form „warfare” z ewolucją struktur społeczno-politycznych. Koncepcja ta wzbudziła szerokie zainteresowanie środowisk naukowych i stała się przedmiotem licznych modyfikacji (m.in. Q. Wright, L. White etc.). Różniły się one pod względem wydzielanych stadiów rozwoju, aczkolwiek ostatecznie potwierdzały wyjściową tezę B. Malinowskiego, że intensywność oraz złożoność konfliktu jest wprost proporcjonalna do stopnia zaawansowania cywilizacyjnego. Doprowadziło do to upowszechnienia się przekonania o niskiej śmiertelności oraz rytualnym charakterze „wojny pierwotnej” (Turney-High 1949, s. 141-168; Wright 1942, s. 85-88). Rzeczona idea stała się podstawą wykładni „gołębic”. Głosiła bowiem, że wojna to zjawisko stosunkowo późne, ponieważ jego początki można z pewną dozą ostrożności sytuować w okresie epipaleolitu/mezolitu. Dużo bardziej prawdopodobne wydaje się jednak przypuszczenie, że praktyka ta ma młodszy, neolityczny rodowód. Argumentów na rzecz tej hipotezy dostarczają przede wszystkim badania archeologiczne (por. Ferguson 2013). Analiza najwcześniejszych materialnych świadectw „warfare” wskazuje na intensyfikację zjawiska w okresie neolitu oraz jego znaczne zróżnicowanie czasoprzestrzenne (Ferguson 2013, również Haas 1998). Kulturowe koncepcje „warfare” negują forsowany przez ,jastrzębie” pandemiczny charakter wojny, uznając ją za formę adaptacji społeczności ludzkich do zmieniających się warunków środowiskowo-historycznych. Generalny przegląd tych teorii znaleźć można m.in. w pracy I.J.N. Thorpe'a (2005). W niniejszym artykule ograniczymy się do prezentacji kilku wybranych propozycji autorstwa Marvina Harrisa, Roberta Briana Fergusona oraz Keitha Otterbeina.

\section{Ekologia kulturowa}

Jest to nurt badawczy, wypracowany na gruncie antropologii amerykańskiej w drugiej połowie XX w., silnie inspirowany myślą marksistowską. Opiera się na założeniu, że środki produkcji pozostające $\mathrm{w}$ dyspozycji danej społeczności determinują charakter jej praktyk społeczno-kulturowych z ideologią włącznie (Harris 1979). Marvin Harris, twórca tej koncepcji, dystansuje się wobec socjobiologiczne- 
go paradygmatu o genetycznym podłożu przemocy. Jego zdaniem o obecności bądź braku konfliktów decydują dwa czynniki - sytuacja demograficzna oraz dostępność surowców niezbędnych do przetrwania. W wyniku pojawienia się nowych środków produkcji zwiększa się wydajność gospodarki, a w konsekwencji dostępność pożywienia. Prowadzi to do niekontrolowanego wzrostu demograficznego oraz zachwiania równowagi między zapotrzebowaniem na pokarm, w szczególności białko zwierzęce, a naturalną produktywnością zasiedlanych nisz ekologicznych. W odpowiedzi na zwiększoną konkurencję o dostęp do ograniczonych źródeł pożywienia dochodzi do wybuchu konfliktu. Intensyfikacja działań zbrojnych redukuje gęstość zasiedlenia oraz wprowadza jej bardziej zrównoważoną dystrybucję. Ponadto prowadzi do powstania stref ,ziemi niczyjej”, odgradzających zwaśnione strony. Ryzyko związane z penetracją owych stref skutecznie odstrasza potencjalnych intruzów, w związku z czym w ich obrębie dochodzi do odnowienia zasobów zwierzyny łownej. Ze względu na zwiększone zapotrzebowanie na wojowników, w warunkach czynnego konfliktu dochodzi również do wzrostu liczby przypadków dzieciobójstwa na niemowlętach płci żeńskiej. Ograniczenie liczby kobiet powoduje stopniowy spadek przyrostu naturalnego, a tym samym przyczynia się do redukcji antropopresji. „Warfare" jest zatem mechanizmem gwarantującym przywrócenie delikatnej równowagi społeczno-środowiskowej. Nie jest to jednak proces o podłożu biologicznym (M. Harris, 2006). Mimo wyraźnych nawiązań do marksizmu, ekologia kulturowa jest silnie osadzona w popularnym w antropologii amerykańskiej determinizmie kulturowym. Opiera się bowiem na deterministycznej koncepcji kultury, według której kultura stanowi zespół form zachowania zmieniających się w wyniku adaptacji do różnorodnych warunków środowiskowych. Podobnie jak darwiniści społeczni, przedstawiciele ekologii kulturowej uważają ,warfare” za jeden z instrumentów ewolucji, aczkolwiek przedmiotem ich badania nie jest sukcesja genów, lecz praktyk oraz norm konstytuujących kulturę (Dawson 1996). Według D. Dawsona ekologia kulturowa dobrze wpisuje się w neorussojańską koncepcję wojny. W miejsce spencerowskiego „przetrwania najlepiej dostosowanych” wprowadza bowiem kategorię wzmiankowanego społeczno-środowiskowego equilibrium, którego wyrazem jest stabilna egzystencja oraz utrwalanie dotychczasowego status quo. Wojna miała zatem pozytywny wpływ na funkcjonowanie społeczności ludzkich w przeszłości, zapewniając im stopniowy, zrównoważony rozwój (Dawson 1996, s. 21-23).

Krytyka omawianej teorii wojny odnosi się przede wszystkim do instrumentalnego traktowania głównych aktorów konfliktu. Determinizm infrastrukturalny, a więc przekonanie o nadrzędnej roli infrastruktury w procesie kształtowania się zjawisk z zakresu struktury i superstruktury ogranicza znaczenie czynnika ludzkiego do minimum, przypisując ludziom rolę nieświadomych wykonawców „woli” reifikowanej kultury. Zwrócono ponadto uwagę, że ekologiczne modele ,warfare” znajdują zastosowanie wyłącznie w badaniach społeczności o prostej, niescentralizowanej strukturze politycznej. W odpowiedzi na zarzuty podjęto próby udoskonalenia 
wyjściowej wersji teorii (Ferguson 2001, s. 100-102). Doprowadziło to do odrzucenia przeświadczenia o dominującej roli infrastruktury, a w konsekwencji uznania aktywnej roli jednostki i możliwości wywierania przez nią wpływu na przebieg działań wojennych. Jedną z lepiej udokumentowanych modyfikacji materializmu kulturowego Marvina Harrisa jest wersja Roberta Briana Fergusona. Była ona wielokrotnie aplikowana zarówno na gruncie badań współczesnych, jak i pradziejowych społeczności przedpaństwowych (Ferguson 2001).

\section{Późniejsze przykłady aplikacji teorii wywodzących się z nurtu materialistycznego oraz „Tribal Zone Theory”}

Wykładnia wojny według R.B. Fergusona zakłada, że leży ona w materialnym interesie osób podejmujących bezpośrednią decyzję o jej wywołaniu. W przypadku starożytnych społeczeństw wodzowskich oraz wczesnych państw zwycięstwo w konflikcie legitymizowało oraz utrwalało instytucję władzy (Arkush, Allen 2006). Wbrew pozorom zjawisko to zachodzi również w przypadku niescentralizowanych systemów politycznych, gdzie nieformalni przywódcy, mimo wyraźnie ograniczonych prerogatyw, potrafią skutecznie wywierać wpływ na decyzje pozostałych członków społeczności, a potencjalne zwycięstwo może ten wpływ znacząco poszerzyć. Podobnie jak większość współczesnych antropologów, R.B. Ferguson postanowił przetestować swoją wyjściową hipotezę na przykładzie ludu Yanomamo, zamieszkującego lasy deszczowe na obszarze dzisiejszej Wenezueli i Brazylii. Owo plemię znane jest ze swojej wojowniczości, której przyczyny są szeroko dyskutowane przez przedstawicieli praktycznie wszystkich współczesnych teorii wojny (por. Chagnon 2013, Ferguson 2001). Analizując przebieg oraz charakterystykę geograficzną konfliktów Indian Yanomamo, R.B. Ferguson doszedł do wniosku, że nie są one wynikiem walk o partnerki seksualne lub egzekucji prawa zemsty rodowej. Te i inne czynniki stanowiły jedynie pochodną splotu okoliczności natury politycznohistorycznej, wywołanych pojawieniem się osadników europejskich oraz ich postępującej ekspansji kulturowej, której towarzyszył m.in. handel z ludnością autochtoniczną. W przypadku społeczności Yanomamo czynnikiem inicjującym działania zbrojne była konkurencja o narzędzia metalowe, będące jednym z towarów oferowanych przez kupców europejskich. Ich zastosowanie znacząco poprawiało wydajność gospodarki kopieniaczej Indian, w związku z czym popyt na nie utrzymywał się na stałym, wysokim poziomie. Rezydujące w pobliżu europejskich osad grupy autochtonów w krótkim czasie zapewniły sobie wyłączny dostęp do narzędzi, co wzbudziło niepokój społeczności zasiedlających bardziej odległe obszary. Nierównomierny dostęp do dóbr materialnych doprowadziła do pierwszych konfliktów między Indianami. Grupy posiadające monopol na handel z Europejczykami broniły zaciekle swojej pozycji ekonomiczno-politycznej przed atakami konkurentów chcą- 
cych zająć ich miejsce. Podobnie jak w klasycznej wersji materializmu kulturowego, główną przyczyną wojny była wzmożona konkurencja o dostęp do pożądanych dóbr występujących w ograniczonej ilości. Jednakże sama chęć wejścia w posiadanie tych przedmiotów stanowiła często wyraz jednostkowych ambicji przywódców plemiennych. W ramach swoich ograniczonych prerogatyw dokonywali oni moralnej konwersji indywidualnych dążeń. Proces ten polegał na próbie nadania partykularnym interesom uwarunkowanym siecią relacji politycznych rangi przedsięwzięcia grupowego, posiadającego kluczowe znaczenie dla wszystkich członków wspólnoty. Przykładowo, umotywowana jednostkowo chęć wyruszenia na wojnę nie mogła zostać poddana pod głosowanie w swojej oryginalnej postaci, ponieważ niemal na pewno spotkałaby się ze sprzeciwem części potencjalnych uczestników. Dlatego też niejednokrotnie prawdziwy cel przedstawiano w taki sposób, aby ukryć prawdziwe intencje podżegacza. Wojownicy ludu Yanomamo często organizowali wyprawy wojenne w odpowiedzi na zdarzenia losowe, uważane za wynik wrogiej działalności, szczególnie w typie czarownictwa. W przypadku sugestywnie uargumentowanego oskarżenia o czary interwencja zbrojna szybko urastała do rangi jedynej możliwej reakcji. Moralna konwersja partykularnych interesów może mieć dwojaki charakter - niekiedy jest to jawna manipulacja, aczkolwiek w pewnych przypadkach jednostka inicjująca konflikt może być głęboko przekonana o słuszności swojego postępowania. Postawa ta występuje często wśród ludów o silnych tradycjach wojowniczych, które odpowiedzialność za wybuch konfliktu przypisują zazwyczaj stronie przeciwnej.

W koncepcji „warfare” autorstwa R.B. Fergusona szczególne miejsce zajmuje problem kontaktu między jednostkami politycznymi o scentralizowanej strukturze państwami a egalitarnymi społecznościami przedpaństwowymi, pozbawionymi trwałej, dziedzicznej instytucji władzy. Jego autorska Tribal Zone Theory, opublikowana po raz pierwszy w tomie The Blood of Leviathan (1990), była odpowiedzią na rosnące zainteresowanie wpływem polityki kolonialnej na zmiany o charakterze społeczno-kulturowym, dokonujące się na gruncie społeczności tubylczych. Praca miała na celu konceptualizację roli zdarzeń historycznych, polegającą na teoretycznym określeniu zasięgu ich oddziaływania oraz wskazaniu nowych problemów badawczych związanych z aplikacją perspektywy historycznej do badań antropologicznych (Ferguson 2006, s. 477). Trzon fergusonowskiej koncepcji „warfare” zawiera się w samym tytule publikacji - krew Lewiatana symbolizuje zupełnie odmienną od hobbesowskiej, a więc konfliktogenną rolę państwa. R.B. Ferguson, a później również Neil Lancelot Whitehead konsekwentnie forsowali tezę, według której na styku granic administracyjnych państw kolonialnych oraz obszarów zasiedlanych przez społeczności przedpaństwowe powstawały tzw. tribal zones. Były to obszary zasiedlane przez autochtonów, formalnie niepodlegające jurysdykcji państwa, lecz pozostające w orbicie jego wpływów ekonomiczno-kulturowych. W dyskutowanym przypadku stymulująca rola kontaktu sprowadzała się przede wszystkim do intensyfikacji działań wojennych oraz przekształcenia dotychczasowych, natyw- 
nych schematów „warfare”. Co więcej, obaj autorzy zgodnie uważają, że w niektórych sytuacjach szeroko pojęta ekspansja osadnictwa kolonialnego mogła prowadzić do dalszej eskalacji wojny. Tribal Zone Theory zdecydowanie poszerza, a przy tym komplikuje obraz czynników determinujących występowanie lub brak konfliktów. R.B. Ferguson uważa, że nowożytne raporty etnograficzne służące niekiedy za punkt wyjścia dla niektórych teorii wojny pierwotnej zawierają informacje o już przekształconych wzorcach „warfare”, mylnie uznawanych za metody walki stosowane jeszcze w okresie prekolumbijskim. W związku z tym arbitralne przenoszenie tych historycznie udokumentowanych wzorców na grunt prahistoryczny stanowi, zdaniem Fergusona i Whiteheada, działanie nieuzasadnione. Wszelkie próby interpretowania konfliktów historycznych powinny uwzględniać stojące za nimi procesy. Nie oznacza to jednak negacji znaczenia czynników lokalnych, strukturyzujących dostępny poznaniu wymiar przemocy. Owa metoda badawcza nie wyklucza ponadto możliwości istnienia konfliktów w okresie poprzedzającym kontakt.

Rzeczona perspektywa badawcza stwarza konieczność rewaloryzacji hipotez badawczych nieuwzględniających „konfliktotwórczej” roli kontaktu ze scentralizowanymi systemami politycznymi. Dzieje się tak, ponieważ część zjawisk uważanych do tej pory za przejaw pierwotnej formy konfliktów przednowoczesnych może w rzeczywistości reprezentować odbicie przekształconych wzorców europejskich. Nie oznacza to jednak, że realne poznanie praktyki „warfare” dostępne jest jedynie w strefie oddziaływania scentralizowanych systemów politycznych. R.B. Ferguson wskazuje, że dotarcie do zrębów wojny w społecznościach przedpaństwowych możliwe jest za pośrednictwem metod archeologicznych oraz krytycznej analizy wczesnych raportów etnograficznych.

Tribal Zone Theory wpisuje się w nurt studiów z zakresu materializmu kulturowego, aczkolwiek wyraźnie dystansuje się od jego wersji neomaltuzjańskiej (Ferguson 2001, s. 100-104). Wojna nie jest zatem rezultatem postępującej antropopresji prowadzącej do konkurencji o ograniczone zasoby kluczowych dla przeżycia surowców. Stanowi raczej wyraz jednostkowych, uwarunkowanych politycznie interesów, których dynamika jest w pewnym stopniu uzależniona od synchronicznych czynników natury historycznej. Relacja państwo - społeczności plemienne, która prowadzi do powstania wzmiankowanych ,tribal zones”, przywodzi na myśl model E. Wallensteina określany mianem World System Theory, na co zwrócił uwagę m.in. Keith Otterbein (2004, 28-29).

\section{Koncepcja dwutorowego rozwoju wojny Keitha Otterbeina}

Zestawienie „kulturowych” teorii wojny zamyka propozycja Keitha Otterbeina. Wyłożył on jej podstawy teoretyczne w publikacji How War Began z 2004 r. Ze względu na swój synkretyczny charakter koncepcja ta wymyka się próbom jedno- 
znacznej klasyfikacji. Łączy bowiem dwa przeciwstawne nurty w sugestywną całość, której cechą charakterystyczną jest wydzielenie nie jednej, lecz dwóch autonomicznych ścieżek rozwoju zjawiska „warfare” (Otterbein 2004). Pierwsza, postulująca długą genezę konfliktu, bazuje głównie na przesłankach biologicznych i odwołuje się do mitu ,zabójczej małpy”. Druga natomiast akcentuje znaczenie gospodarki wytwarzającej oraz zmian społeczno-politycznych, do których doszło w wyniku jej upowszechnienia. Co istotne, ewolucja działań zbrojnych według K. Otterbeina nie miała charakteru unilinearnego. Warunkiem niezbędnym do zaistnienia etapu drugiego nie jest kontynuacja pierwotnych wzorców „,warfare”, lecz ich całkowity zanik.

Rajdy i zasadzki, zaliczane obok bitew do podstawowych taktyk walki społeczności przedpaństwowych (Otterbein 2009, s. 11-22), były naturalną konsekwencją funkcjonowania patrylokalnych społeczności łowieckich, zorganizowanych na podstawie więzów krewniaczych. Wzmiankowane formy działań zbrojnych miały zdaniem badacza bardzo odległą genezę sięgającą swymi początkami milionów lat w przeszłość. Intensyfikacja przemocy zorganizowanej miała nastąpić w epoce paleolitu, gdy podstawowym pożywieniem grup ludzkich było mięso gatunków zwierzyny łownej zaliczanych do megafauny (2004, s. 12). Natomiast do stopniowej deeskalacji konfliktów zbrojnych doszło wskutek ich wymierania oraz zastępowania gatunkami mniejszymi. Postępująca stabilizacja osadnictwa, związana ze spadkiem mobilności grup ludzkich w epoce mezolitu (Vencl 1984, s. 119-122) oraz zwiększający się udział zbieractwa w gospodarce ówczesnych populacji doprowadziły do zaniku „warfare”. Z kolei na obszarach wolnych od działań wojennych rozpoczęła się domestykacja roślin uprawnych. Według K. Otterbeina był to złożony proces trwający około dwa tysiące lat (2004, s. 13). Jeśli w tym czasie nastąpiła ponowna eskalacja działań wojennych, ulegał on zahamowaniu, ponieważ w obawie przed atakami ludność musiała porzucić żyzne ziemie uprawne i osiedlić się na obszarach mniej urodzajnych, ale łatwiejszych do obrony. Natomiast długotrwały okres pokoju sprzyjał rozwojowi społeczności ludzkich - na skutek przyrostu demograficznego zwiększał się także obszar zajmowany przez poszczególne grupy. Niewielkie osady ulegały przekształceniu w wioski, a ich koncentracje odzwierciedlały zasięg poszczególnych tradycji kulturowych. Akumulacja bogactwa przez niektóre jednostki lub rody doprowadziła do wykształcenia się zrębów stratyfikacji społecznej oraz nieformalnej instytucji przywódcy. Rywalizacja na tle ekonomiczno-politycznym między doraźnymi przywódcami doprowadziła do wewnętrznych walk o władzę. Jednostki, które odniosły zwycięstwo, utrwalały swoją pozycję i stawały na czele systemów wodzowskich. Te z czasem ewoluowały w pierwsze państwa, a wcześniejsi wodzowie wraz z rodzinami dali początek klasie rządzącej. Idea państwa krzepła powoli, acz konsekwentnie, a przywódcy polityczni sukcesywnie umacniali swoją władzę nad poddanymi. Realizacja celów politycznych wymagała zdecydowanych środków, czego następstwem była wtórna inicjacja oraz eskalacja „warfare”. Początkowo w walkach uczestniczyli wojownicy rekrutujący się z warstwy rządzącej. Postępująca 
centralizacja władzy doprowadziła do rozwoju środków przymusu, co pozwoliło na utworzenie armii, których trzon stanowili obywatele podlegający obowiązkowi werbunkowemu. Według niniejszego schematu wojna nie była zatem przyczyną, lecz konsekwencją rozwoju scentralizowanych systemów politycznych (2004, s. 15), co stoi w sprzeczności z neorussojańską koncepcją ewolucji konfliktów zbrojnych.

\section{ZAKOŃCZENIE}

Analogie etnograficzne oraz historyczne, mimo pewnych ograniczeń związanych $\mathrm{z}$ ich aplikacją $\mathrm{w}$ badaniach na społecznościami pradziejowymi, stanowią jedną z podstawowych kategorii informacji wykorzystywanych w badaniach nad ,warfare”. Badacze europejscy coraz chętniej sięgają po rozwiązania analityczne opracowane przez amerykańskich archeologów i antropologów kulturowych, dostosowując je do specyfiki materiałowo-kontekstualnej społeczności pradziejowych Starego Kontynentu. Szeroko pojęte studia nad wojną coraz częściej odchodzą od typologicznej analizy archeologicznych świadectw „,warfare” na rzecz nadania temu zjawisku bardziej społecznego wymiaru. Niniejszy przegląd obejmuje w zasadzie wyłącznie koncepcje z kręgu anglosaskiego. Nie jest to jednak przejaw jakichś bliżej nieokreślonych preferencji naukowych, lecz raczej odzwierciedlenie faktycznego stanu refleksji. Archeolodzy europejscy z krajów nieanglojęzycznych często interpretują dostępny im materiał, odwołując się bezpośrednio do ustaleń badaczy amerykańskich. Zjawisko to należy interpretować jako wyraźny sygnał do włączenia dynamicznie rozwijającej się oferty studiów nad „warfare” również do archeologii polskiej. Ów proces już trwa, niemniej szersze zrozumienie problemu wymaga choćby pobieżnego zapoznania się z podstawą teoretyczną tej oferty. Celem niniejszego artykułu nie było przedstawienie gotowych wzorców interpretacyjnych, lecz prezentacja najpopularniejszych koncepcji wojny w perspektywie diachronicznej. Jest to zatem przyczynek do refleksji nad rolą przemocy w społecznościach przedpaństwowych - refleksji ostatecznie ukierunkowanej na poszerzenie puli interpretacji dotyczących również europejskich kultur pradziejowych.

Tabela 1. Skrócona charakterystyka bioewolucyjnych oraz kulturowych koncepcji wojny obecnych w piśmiennictwie anglojęzycznym

Table 1. Shortened characteristic of bioevolutinary and cultural concepts of war in English-based literature

\begin{tabular}{|l|l|}
\hline \multicolumn{2}{|c|}{ Teorie bioewolucyjne } \\
\hline Geneza & $\begin{array}{l}\text { Wojna to forma działania kolektywnego, która ukształtowała się i rozwi- } \\
\text { nęła jeszcze na etapie ewolucji gatunku ludzkiego. }\end{array}$ \\
\hline Podłoże & $\begin{array}{l}\text { Ze względu na swój adaptacyjny charakter jest ona zakodowana } \\
\text { w genach. Ma zatem podłoże biologiczne, a wszelkie uwarunkowania } \\
\text { kulturowe mają charakter wtórny. }\end{array}$ \\
\hline
\end{tabular}




\begin{tabular}{|c|c|}
\hline \multicolumn{2}{|r|}{ Teorie bioewolucyjne } \\
\hline Przyczyny & $\begin{array}{l}\text { Podejmowanie działań kwalifikujących się jako akty przemocy zorgani- } \\
\text { zowanej pozwalało uzyskać przewagę nad mniej agresywnymi grupami } \\
\text { biorącymi udział w rywalizacji o pokarm i/lub partnerki seksualne, } \\
\text { a w efekcie przyczyniało się do zwiększenia szans na udaną reprodukcję. }\end{array}$ \\
\hline $\begin{array}{l}\text { Rola wojny w procesie } \\
\text { ewolucji }\end{array}$ & $\begin{array}{l}\text { Wojna to mechanizm wspierający ewolucję zbiorowości ludzkich. Jed- } \\
\text { nostką dziedziczenia jest nie indywidualny organizm, lecz gen. Z per- } \\
\text { spektywy jednostkowej udział w wojnie wydaje się być nieracjonalny, } \\
\text { ponieważ stwarza znaczne ryzyko utraty zdrowia lub życia. Jednak } \\
\text { przyczynia się on do zabezpieczenia puli genowej obejmującej również } \\
\text { najbliższych krewnych. Jednostkowa ofiara pojedynczego osobnika staje } \\
\text { się tym samym gwarantem sukcesji genetycznej pozostałych członków } \\
\text { rodziny. }\end{array}$ \\
\hline Funkcje & $\begin{array}{l}\text { W ujęciu bioewolucyjnym główną funkcją wojny jest zwiększenie szans } \\
\text { na sukces reprodukcyjny na drodze eliminacji potencjalnych rywali } \\
\text { i uzyskania dostępu do ograniczonej liczby partnerek seksualnych. }\end{array}$ \\
\hline Podstawa teoretyczna & $\begin{array}{l}\text { Hipoteza o odległej genezie wojny opiera się na przeświadczeniu } \\
\text { o filogenetycznym pokrewieństwie ludzi i szympansów. U obu gatun- } \\
\text { ków stwierdzono występowanie aktów przemocy zorganizowanej. Po- } \\
\text { nadto w obu przypadkach czynniki determinujące przebieg owych aktów } \\
\text { cechuje duże podobieństwo. Na tej podstawie uznano, że wczesne formy } \\
\text { przemocy zorganizowanej mogły występować już u wspólnego przodka } \\
\text { ludzi i szympansów, który żył najprawdopodobniej ok. } 5 \text { mln lat temu. }\end{array}$ \\
\hline Podstawa źródłowa & $\begin{array}{l}\text { Głównie obserwacje prymatologów badających zachowanie małp człe- } \\
\text { kokształtnych oraz opracowania antropologów zajmujących się proble- } \\
\text { mem wojny w społecznościach przedpaństwowych. Nieliczne materiały } \\
\text { archeologiczne, które ze względu na swój wiek i zły stopień zachowania } \\
\text { stanowią niepewną podstawę do wnioskowania o wysokiej częstotliwo- } \\
\text { ści konfliktów w paleolicie. }\end{array}$ \\
\hline \multicolumn{2}{|r|}{ Teorie „kulturowe” } \\
\hline Geneza & $\begin{array}{l}\text { Wzmożona konkurencja o zasoby środowiska naturalnego występujące } \\
\text { na obszarze intensywnie zasiedlanych i eksploatowanych nisz ekolo- } \\
\text { gicznych; cykliczne wahnięcia klimatyczne oraz niekontrolowany przy- } \\
\text { rost demograficzny wpływały na zaostrzenie konkurencji. }\end{array}$ \\
\hline Podłoże & $\begin{array}{l}\text { Wojna to praktyka o charakterze kulturowym. Kształtuje się oraz rozwija } \\
\text { na skutek adaptacji społeczności ludzkich do zmiennych warunków } \\
\text { środowiskowo-kulturowych. Jej obecności nie należy interpretować } \\
\text { przez pryzmat biologii. Takie działanie uważane jest za niebezpieczne, } \\
\text { ponieważ zdaniem „,gołębic" może stanowić pretekst do moralnego } \\
\text { usprawiedliwienia działań zbrojnych podjętych ze względu na jednost- } \\
\text { kowe interesy. }\end{array}$ \\
\hline Przyczyny & $\begin{array}{l}\text { Według skrajnych deterministów kulturowych do wojen dochodzi } \\
\text { w wyniku zbiegu losowych okoliczności. Jest to chwilowe zaburzenie } \\
\text { funkcjonowania reprodukowanych wzorców kulturowych, które zanika } \\
\text { w krótkim czasie i nie wywiera istotnego wpływu na funkcjonowani } \\
\text { danej społeczności. Według ewolucjonistów społecznych wojny są } \\
\text { naturalną konsekwencją ewolucji struktur społeczno-politycznych. } \\
\text { Ekologia kulturowa (lub ekomaterializm) zakłada, że do działań zbroj- } \\
\text { nych dochodzi w wyniku nadmiernego rozrostu populacji, skutkującego } \\
\text { zaburzeniem równowagi między zapotrzebowaniem na pokarm a pro- } \\
\text { duktywnością niszy ekologicznej. Z kolei nowsze koncepcje o charakte- }\end{array}$ \\
\hline
\end{tabular}




\begin{tabular}{|c|c|}
\hline & $\begin{array}{l}\text { rze materialistycznym akcentują znaczenie aktywnej roli jednostek oraz } \\
\text { okoliczności historycznych, które mogą w sposób znaczący determino- } \\
\text { wać zarówno przyczyny, jak i przebieg konfliktów zbrojnych w społecz- } \\
\text { nościach przedpaństwowych. }\end{array}$ \\
\hline $\begin{array}{l}\text { Rola wojny w procesie } \\
\text { ewolucji }\end{array}$ & $\begin{array}{l}\text { W ujęciu kulturowo-deterministycznym wojna nie wpływa na funkcjo- } \\
\text { nowanie struktur społeczno-kulturowych danej grupy. Według ekomate- } \\
\text { rialistów wojna nie tyle inicjowała i nadawała kierunek zmianom, co } \\
\text { raczej gwarantowała trwałość oraz stabilność owych struktur przez } \\
\text { utrzymywanie delikatnej równowagi między produktywnością ekosys- } \\
\text { temu a potrzebami zasiedlających go populacji. Z kolei K. Otterbein } \\
\text { w ramach swojej eklektycznej koncepcji „warfare” przyjmuje, że czyn- } \\
\text { nikiem niezbędnym do zainicjowania przemian gospodarczych i spo- } \\
\text { łeczno-kulturowych, prowadzących do powstania pierwszych ośrodków } \\
\text { państwowych, jest długotrwały brak konfliktów, rozdzielający dwa } \\
\text { rozłączne etapy rozwoju zjawiska „,warfare”. }\end{array}$ \\
\hline Funkcje & $\begin{array}{l}\text { Adaptacja do zmiennych warunków środowiskowo-kulturowych, me- } \\
\text { chanizm regulujący gęstość oraz dyspersję osadnictwa, przywracający } \\
\text { równowagę zachwianą nadmiernym przyrostem naturalnym. Również } \\
\text { narzędzie realizacji celów jednostkowych, które na skutek moralnej } \\
\text { konwersji urasta do rangi działania obliczonego na poprawienie sytuacji } \\
\text { nie tylko decydenta, lecz całej grupy. }\end{array}$ \\
\hline Podstawa teoretyczna & $\begin{array}{l}\text { Determinizm kulturowy, materializm kulturowy, ekologia kulturowa, } \\
\text { neoewolucjonizm, Tribal Zone Theory - jest to modyfikacja wyjściowej } \\
\text { wersji materializmu kulturowego poszerzona o model relacji państwo- } \\
\text { społeczności przedpaństwowe zaczerpnięty z WST E. Wallensteina. }\end{array}$ \\
\hline Podstawa źródłowa & $\begin{array}{l}\text { Analiza najwcześniejszych materialnych świadectw ,warfare” wskazuje, } \\
\text { że intensyfikacja aktów przemocy zorganizowanej nastąpiła w okresie } \\
\text { zmian klimatycznych, związanych z nastaniem holocenu. Spowodowało } \\
\text { to odejście od mobilnego trybu życia i rozwój trwalszych form osadnic- } \\
\text { twa. Koncentrowało się ono zazwyczaj w obrębie najbardziej produk- } \\
\text { tywnych nisz ekologicznych, które stały się przedmiotem rywalizacji } \\
\text { grup konkurujących o zasoby środowiska naturalnego. }\end{array}$ \\
\hline
\end{tabular}

\section{BIBLIOGRAFIA}

Alexander R.

1979 Darwinism and human affairs. London: Pitman.

Arkush E., Allen M.W. (red.)

2006 The archaeology of warfare: Prehistories or raid and conquest. Florida: Florida University Press.

Buliński T., Kairski M.

2006 Sny, Trofea, Geny i Zmarli. „,Wojna” w społecznościach przedpaństwowych na przykładzie Amazonii - przegląd koncepcji antropologicznych. Poznań: Wydawnictwo Naukowe UAM.

Chagnon N.

2013 Noble Savages. My life among two dangerous tribes - the Yanomamö and the anthropologists (s. 214-378). New York: Simon \& Schuster. 
Cosmides L.

1985 Deduction or Darwinian Algorithms? An explanation of the "elusive" content effect on the Wason selection task. Doctoral dissertation, http://www.cep.ucsb.edu/publist.htm.

Dart R.

1953 The Predatory Transition from Ape to Man. International Anthropological and Linguistic Review, 1, s. 201-217.

Dawson D.

1996 The Origins of War: Biological and Anthropological Theories. History and Theory, 35 (1, Feb.), s. 1-28.

Dawson D.

1999 Theory and Group Selection: The Question of Warfare, History and Theory, 38(4), Theme Issue 38: The Return of Science: Evolutionary Ideas and History (Dec., 1999), s. 79-100.

Durkheim E.

2016 Zasady metody socjologicznej. Warszawa: Wydawnictwo PWN.

Ferguson R.B.

1990 The Blood of Leviathan. Western contact and warfare in Amazonia, http://www.ncas.

Ferguson R.B. rutgers.edu/sites/fasn/files/Blood_of_the_Leviathan.pdf

2001 Materialist, cultural and biological theories on why Yanomami make war, https://www.ncas.

Ferguson R.B. rutgers.edu/sites/fasn/files/Materialist\%20Cultural\%20Biological.pdf

2006 Archaeology, Cultural Anthropology and the Origins and Intensifications of War. W: E. Arkush, M.W. Allen (red.), The archaeology of warfare: Prehistories of raid and conquest (s. 469-523). Florida: Florida University Press.

Ferguson R.B.

2008 Ten Points on War, http://www.ncas.rutgers.edu/sites/fasn/files/Ten\%20Points\%20on\% 20War\%20(2008).pdf

Ferguson R.B.

2013 The Prehistory of War and Peace in Europe and the Near East, http://www.ncas.rutgers. edu/sites/fasn/files/The $\% 20$ Prehistory $\% 20$ of $\% 20$ War $\% 20$ and $\% 20$ Peace $\% 20$ in $\% 20$ Europe \%20and\%20the\%20Near\%20East\%20(2013)_0.pdf

Freud S.

1997 Totem i tabu: kilka zgodności w życiu psychicznym dzikich i neurotyków. Warszawa: Wydawnictwo KR.

Fry D (red.).

2013 War, Peace and Human Nature. The Convergence of Evolutionary and Cultural Views. Oxford: Oxford University Press.

Gat A.

2006 War in Human Civilisation. Oxford: University Press.

Guilaine J., Zammit J.

2005 Origins of War. Violence in Prehistory. Ames, Iowa: Blackwell Publishing.

Haas J.

$1998 \quad$ Warfare and the evolution of culture. Santa Fe: Santa Fe Institute.

Harris M.

1979

Cultural Materialism. The Struggle for a Science of Culture. New York: Random House.

Harris M.

2006 Yanomamo i przyczyny wojen w społeczeństwach kopieniaczych oraz zbieracko-łowieckich. W: T. Buliński, M. Kairski (red.), Sny, Trofea, Geny i Zmarli. „,Wojna” w społecz- 
nościach przedpaństwowych na przykladzie Amazonii - przegląd koncepcji antropolo-

Hobbes T. gicznych (87-108). Poznań: Wydawnictwo Naukowe UAM.

2005 Lewiatan, czyli Materia, forma i władza państwa świeckiego i kościelnego. Warszawa: Państwowe Wydawnictwo Naukowe.

Keeley L.H.

1996 War Before Civilisation. New York, Oxford: Oxford University Press.

LeBlanc S.A., Register K.E.

2003 Constant Battles: The Myth of Peaceful, Noble Savage. New York: St. Martin's Press.

Malinowski B.

1940 An Anthropological Analysis of War. American Journal of Sociology, 46, s. 521-550.

Mead M.

1940 Warfare is Only an Invention - Not a Biological Necessity, http://users.metu.edu.tr/ utuba/Mead.pdf

Otterbein K.

2004 How War Began (s. 3-38). Texas: A\&M University Press.

Pinker S.

2011 The Better Angels of Our Nature: Why Violence has Declined. London: Penguin Books.

Przybyła M.

2014 Teoria ewolucji w archeologicznych badaniach nad dawnymi spoleczeństwami (Prace Archeologiczne 67). Kraków. Instytut Archeologii UJ.

Rousseau J.J.

1966 Umowa Spoleczna. Warszawa: Wydawnictwo PWN.

Spencer H.

1851 Social Statics, http://oll.libertyfund.org/people/165.

Sussman R., Marshack J.

2010 Are Humans Inherently Killers? A Critique by Robert Sussman and Joshua Marshack Followed by a Response by Richard Wrangham. Global Nonkilling Working Papers,

Thorpe I.J.N.

http://nonkilling.org/pdf/wp1.pdf.

2005 The ancient origins of warfare and violence. W: M.P. Pearson, I.J.N Thorpe (red.), Warfare, violence and slavery in prehistory: proceedings of a Prehistoric Society conference at Sheffield University (BAR International Series, 1374, s. 1-18). Oxford: Archaeopress.

Tooby J., Cosmides L.

1988 The Evolution of War and its Cognitive Foundations. Institute for Evolutionary Studies Technical Report 88-1.

Turney-High $\mathrm{H}$.

1949 Primitive War. Its Practice and Concepts (s. 21-137). Columbia: University of South Caroline Press.

Vencl S.

1984 War and Warfare in Archaeology. Journal of Anthropological Archaeology, 3, s. $116-132$.

Wilson E.O.

1978 On Human Nature, Cambride MA: Harvard University Press.

Wrangham R., Peterson D.

1999 Demoniczne Samce. Matpy czlekoksztaltne i źródta ludzkiej przemocy (s. 7-311). Warszawa: Państwowy Instytut Wydawniczy. 
Wrangham R.

2010 Chimpanzee Violence is a Serious Topic: A response to Sussman and Marshack's critique of Demonic Males: Apes and the Origins of Human Violence, Global Nonkilling

Wright Q. Working Papers, http://nonkilling.org/pdf/wp1.pdf.

1942 A Study of War (s. 85-88). Chicago: University of Chicago Press. BIOLOGIA VERSUS KULTURA. PRZEGLACD BIOEWOLUCYJNYCH I KULTUROWYCH
TEORII WOJNY W PRZEDPAŃSTWOWCH SPOŁECZNOŚCIACH PRADZIEJOWYCH

\section{Summary}

The controversy over the nature of the primitive man goes back to 'The Social Contract', where J.J. Rousseau presented an idyllic concept of a pristine state of humanity, whereby prehistoric people know nothing of violence, living in peaceful harmony. The vision was very different from an earlier idea of Thomas Hobbes, who argued that a prehistoric man was a 'savage brute', whose life was 'solitary' and 'poor'. Soon after that a serious discussion arose; sharp divisions were made and ideological and intellectual war on warfare, particularly its origins, began. 'Hawks' and 'doves' have been trying to determine the real nature of conflict - is it a biological necessity, an inherent part of natural selection in human evolution or maybe some form of cultural adaptation for rapidly changing environmental and demographical conditions? Despite a large number of contributors from natural (primatology) and medical (paleopathology) sciences, the question still remains open. 